\title{
GRAVITY AND AEROMAGNETIC MAPS OF THE ELY AREA, WHITE PINE COUNTY, NEVADA
}

By

J. E. Carlson and D. R. Mabey

GEOPHYSICAL INVESTIGATIONS

MAP GP-392

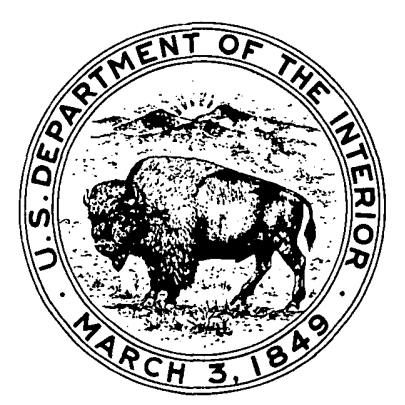

PUBLISHED BY THE U.S. GEOLOGICAL SURVEY 


\title{
GRAVITY AND AEROMAGNETIC INVESTIGATIONS OF THE
}

\author{
ELY AREA, NEVADA \\ By \\ J. E. Carlson and D. R. Mabey
}

\section{INTRODUCTION}

The Ely area of this report consists of about 1850 square miles around the city of Ely in east-central Nevada. A Bouguer gravity anomaly map (A) has been prepared from a reconnaissance gravity survey made in 1960 of the Ely area, and a total intensity aeromagnetic map (B) has been prepared from an aeromagnetic survey made in 1961 of the central part of the area. The geology is generalized from the Guidebook to the geology of east-central Nevada, (1960).

\section{PHYSIOGRAPHY AND GENERAL GEOLOGY}

The dominant physiographic units are northtrending ranges separated by alluvial valleys. These units are the central parts of the Schell Creek, Egan, and White Pine Ranges; and the western edge of Spring Valley, the central part of Steptoe Valley, northern White River Valley, and Jakes Valley. The highest point is North Schell Peak in the Schell Creek Range at 11,890 feet above sea level, and the higher peaks in all of the ranges are over 9,000 feet above sea level.

Most of the bedrock in the ranges is Precambrian and Paleozoic sedimentary rock. Precambrian rocks occupy small areas in the Schell Creek Range, in the Egan Range west of McGill, and in the Connors Pass area. These older rocks are at least 10,000 feet thick and consist mainly of quartzite, interbedded with phyllitic and quartzitic shale. Paleozoic rocks consist mainly of limestone, dolomite, and quartzite, and théy increase in thickness southward to about 18,000 feet in the Egan Range at the southern edge of the map (Brokaw, written communication, 1962).

Non-marine sedimentary and volcanic rocks of Cenozoic age overlie the Paleozoic rocks unconformably. The Tertiary sedimentary rocks that are exposed in relatively small areas consist of conglomerate, sandstone, siltstone, and freshwater limestone. In some areas these sedimentary rocks are interbedded with pyroclastic rocks. Tertiary volcanic rocks are exposed over wide areas in the Egan Range north of Ruth, south of Jakes Valley, and locally in other areas. These rocks are mostly andesite, rhyolite, and welded rhyolite tuff, although some basalt is also present. Quaternary alluvium covers most of the valley areas and is locally present in the ranges.

Post-Paleozoic intrusive igneous rocks are exposed in only a small part of the survey area and consist mainly of monzonite porphyry or granite. Some parts of the small bodies shown as volcanic rocks in the south part of the Egan Range are intrusive rhyolite (Shawe, 1961).
The structure in the pre-Tertiary rocks in the ranges is generally complex, and similar structure probably underlies the valleys. Numerous high-angle faults occur in all the ranges, and large scale thrust faults and folds are found in some but not all of the ranges. Locally, large high-angle faults are inferred at the range fronts.

Density measurements of rocks in the Ely area agree with those made in adjoining areas and fall into three general density groups. The unconsolidated or poorly-consolidated Cenozoic sedimentary rocks have the lowest density, ranging from 2.0 to $2.3 \mathrm{~g}$ per $\mathrm{cm}^{3}$. The Cenozoic volcanic rocks cover a wide density range but average about $2.45 \mathrm{~g}$ per $\mathrm{cm}^{3}$. The Paleozoíc and Precambrian sedimentary rocks and postPaleozoic intrusive rocks have a density range of 2.6 to $2.8 \mathrm{~g}$ per $\mathrm{cm}^{3}$ and average about $2.7 \mathrm{~g}$ per $\mathrm{cm}^{3}$.

\section{GEOPHYSICAL SURVEYS}

Gravity measurements were made with a Worden gravity meter and were referred to the airport base station at Ely established by Woollard, (1958). A density factor of $2.67 \mathrm{~g}$ per $\mathrm{cm}^{3}$ was used for the Bouguer correction, and sea level is the datum for both freeair and Bouguer corrections. Theoretical gravity was computed from the international formula.

Terrain effect is small in the center of the valleys and large in the higher parts of the ranges. Cor rections for all terrain effect over 3 mgals were applied to stations where terrain effect is greater than 3 mgals within 7.7 miles of the station. The largest terrain correction within a radius of 100 miles of the station is 34 mgals for a station at 10,740 feet altitude in the Schell Creek Range; however, most are much smaller. Error in the gravity data is mainly in the terrain effect component, and the error is in excess of $3 \mathrm{mgals}$ at those stations where terrain effect is greater than 3 mgals.

Horizontal and vertical control for most of the 460 gravity stations was obtained from bench marks and spot altitudes shown on the U. S. Geological Survey topographic maps. Control for the remaining stations was obtained by plane-table surveys.

The aeromagnetic survey was made with a modified AN/ASQ-3A magnetometer. This unit records continuous total intensity aeromagnetic data through a fluxgate detecting element towed about 75 feet below a DC-3 aircraft. North-south flight lines spaced two miles apart were flown at a barometric elevation of 11,500 feet above sea level. The actual flight paths were recorded by a gyrostabilized continuous strip- 
film camera. These data were then compiled as a total intensity magnetic contour map.

\section{GENERAL INTERPRETATION}

The Bouguer gravity values over Paleozoic rocks range from about -205 mgals to about -225 mgals. The anomaly values are mostly below -215 mgals in the Egan Range near McGill and south of Ruth, and in the southern Duck Creek and Schell Creek ranges. How ever, over most of the Paleozoic rocks north and west of Ruth and in the northern part of the Duck Creek Range, the anomaly values are generally higher than -215 mgals.

Each of the major valleys are areas of low gravity values. Steptoe Valley contains the low of greatest magnitude--about 25 mgals near the center of the valley. Jakes Valley contains a low of 15 mgals and a smaller low was measured in White River Valley.

The largest magnetic anomaly is a high of about 400 gammas centered over the southern boundary of the Robinson mining district at Ruth. This local high is part of a positive magnetic anomaly which covers most of the Egan Range from Ruth to the southern edge of the map. The east side of White River Valley is also covered by the larger anomaly. The magnetic high near McGill in Steptoe Valley trends southwest into the Egan Range. The southwestern edge of a high over the southern Duck Creek Range is shown along the eastern edge of the map. Several magnetic anomalies were measured over the Tertiary volcanic rocks in the northwestern corner of the magnetic map.

\section{DETAILED INTERPRETATION}

Quantitative results given in this report were derived in the following manner. Depths, based on magnetic anomalies were determined by the method described by Vacquier and others (1951). Thicknesses in alluvial areas were computed using the gravity formula given by Thompson and Sandbers (1958, p. 1272).

Egan Range. A large magnetic high is centered over the southern edge of the Robinson mining district at Ruth where disseminated copper deposits occur in an east-trending zone of metamorphosed sedimentary rocks and altered monzonite porphyry. The nearsurface igneous rocks associated with the copper deposits could produce part of the magnetic anomaly, but the major part is produced by a large, partly concealed, intrusive body.

A magnetic high was mapped over the Egan Range about 12 miles south of Ely, west of the Ward mining district. Most of the range under the magnetic anomaly cons ists of Paleozoic sedimentary rocks, but the anomaly shows that a large mass of magnetic rock intrudes the range and extends under the eastern side of White River Valley. The top of the main magnetic mass is estimated at 3,000 feet above sea level. The anomaly is similar, although slightly smaller in horizontal extent and amplitude, to the anomaly at Ruth. We interpret it as a reflection of intrusive rock of the same type as that at Ruth. The occurrence of monzonite dikes near the magnetic high (Brokaw, written communication, 1962 ) is further evidence of a buried intrusive. The zone of high magnetic intensity between the two local anomalies suggests that the igneous bodies that produced them are connected.
A geochemical survey in the area of the southern magnetic high in the Egan Range showed that anomalous amounts of $\mathrm{Ag}, \mathrm{Hg}, \mathrm{Cu}, \mathrm{Pb}, \mathrm{Zn}, \mathrm{Mo}, \mathrm{Sb}, \mathrm{W}$, and $\mathrm{Sn}$ are present in jasperoid and in iron-rich fracture filling in the limestone and dolomite along and adjacent to ma jor faults (Brokaw and others 1962). West of the geochemical anomaly the magnetic high extends beyond the bedrock exposures into an area covered by Quaternary alluvium. The gravity data suggest that the bedrock under part of this area may lie at depths shallow enough to justify more geophysical exploration for economic minerals.

A magnetic high was mapped near the center of Steptoe Valley west of McGill. This high probably reflects the northeastward trend under the valley of the granitic intrusive of Heusser Mountain in the Egan Range north of Ely.

In the Egan Range northeast of Jakes Valley, Tertiary volcanic rocks are exposed in an area of moderate relief. The gravity values over this area are not markedly different from those on Paleozoic rock in adjoining areas and indicate either that the volcanic rocks are thin or have about the same density as the Paleozoic rocks. The volcanic rocks are covered on the magnetic map by an area of alternate highs and lows. The cause of these local magnetic anomalies over the volcanic rocks is not known but the anomalies may be related to intrusive rocks near the surface or to eruptive centers.

Where pre-Tertiary rocks are exposed in the Egan Range, the gravity values show an inverse correlation with the magnetic intensity. Over those parts of the range where the magnetic data indicate buried magnetic rocks the Bouguer anomaly values are generally lower than over other parts of the range. This relationship suggests that the rocks producing the magnetic anomalies have a lower density than either the sedimentary rocks or rocks of the basement complex. A correlation between granitic intrusive rocks and negative gravity anomalies has been established by Bott (1953). These magnetic and gravity anomalies could be produced by intrusive granitic rocks; therefore, these data are consistent with the hypothesis that a large granitic body (or bodies) intrudes the Egan Range south of Ruth, and north of Ely along the east side of the range. If the crystalline basement rock is assumed to be more dense than rocks of the sedimentary section the general southward decrease in the gravity values may also reflect a thickening of the Paleozoic and Precambrian sedimentary rocks to the south and an increase in the depth to the basement rock.

Steptoe Valley. A prominent gravity trough with three areas of closure extends along the part of Steptoe Valley on this map. A Bouguer anomaly value of $-252 \mathrm{mgal}$ in the southern part of the valley is the lowest reported in Nevada. The computed thickness of Cenozoic rocks underlying the valley is about 10,000 feet south of McGill, and about 7,500 feet near Ward. The density contrast factor of $0.4 \mathrm{~g}$ per $\mathrm{cm}^{3}$ used in the computations is probably valid if the valley does not contain significant amounts of lake bed deposits. If these deposits are present in large amounts the density contrast between the bedrock and the alluvial material would be larger and the computed depths would be less (Kane and Pakiser, 1961). Gravity gradients that are probably produced by high angle faults with 
large vertical displacements were measured on both sides of the valley and indicate that the gross structure of the valley at least in the northern part, is a graben. These gradients are as much as 17 mgals per mile near McGill.

A magnetic high at the north end of the valley near McGill has gradients that indicate a depth to source of about 4,000 feet. The gravity data in the area of the magnetic anomaly indicate that the fill is at least $4,0,00$ feet thick and perhaps thicker, depending upon the choice of density contrast factors. South of the anomaly the gravity data indicate a depth to bedrock as great as 10,000 feet. A fault interpreted from the gravity data is close to the eastern edge of the magnetic anomaly. The magnetic anomaly is probably produced by an intrusive body in the pre-Tertiary rocks that underlie the valley; but possibly it is produced by Tertiary volcanic rocks or by rocks intrusive into the Cenozoic rocks. The intrusive rock may also account for part of the gravity low.

Jakes Valley Area. The gravity low in Jakes Valley could be produced by a depression filled with about 3,000 feet of Cenozoic rocks which have a density 0.4 per $\mathrm{cm}^{3}$ lower than the enclosing rocks. South of Jakes Valley a broad low-amplitude gravity low was measured in an area underlain by Tertiary volcanic rocks and minor Quaternary alluvium. About 2,000 feet of volcanic rocks could produce the measured anomaly. The gradient along the west boundary of the volcanic rock suggests a fault contact between the volcanic and adjacent Paleozoic rocks. The lowest gravity values in this low are over Quaternary alluvium along Ellison Creek near the southwest edge of the map. These values probably reflect either the difference in density between alluvium and the volcanic rock or a local deeper depression in the surface of the pre-Tertiary rock. Only a few gravity measurements were made in the mountains east of Jakes Valley; however, no significant change in gravity was noted.

White River Valley. A small gravity low was measured in White River Valley where scattered exposures of Paleozoic rocks and Tertiary rocks are enclosed by alluvium. It is not possible to fully analyze the valley anomaly owing to a lack of gravity measurements in the western Egan Range; however, if bedrock gravity values are taken from the gravity contours, the resid- the western Egan Range; however, if bedrock gravity values are taken from the gravity contours, the residual amplitudes in the valley range from 5 to 15 mgals. This range represents 1,000 to 3,000 feet of Cenozoic fill.

The part of the gravity low that includes the two -230 mgal contours is closely related to the magnetic high west of Ward. If this magnetic high is caused by a granitic mass, then part, or most, of the gravity low could also be caused by the intrusive. In this case, the thickness of Cenozoic fill given above would be too great. Because of the absence of magnetic anomaly in the northern part of the valley, we can probably conclude that the lower gravity there is caused by Cenozoic fill as thick as 1,000 feet.

\section{REFERENCES CITED}

Bott, M. P. H., 1953, Negative anomalies over acid "intrusions" and their relation to the structure of the earth's crust: Geol. Mag. No. 90, p. 257267.

Brokaw, A. L., Gott, G. B., Mabey, D. R., McCarthy, Howard, and Oda, Uteana, 1962, Mineralization associated with a magnetic anomaly in part of the Ely quadrangle, Nevada: U. S. Geol. Survey Circular $475,7 \mathrm{p}$.

Intermountain Association of Petroleum Geologists, 1960, Guidebook to the geology of east-central Nevada: 11th Annual Field Conference, $264 \mathrm{p}$.

Kane, M. F., and Pakiser, L. C., 1961, Geophysical study of subsurface structure in southern Owens Valley, California: Geophysics, v. 26, No. 1, p. 12-26-

Shawe, D. R., 1961, Rhyolites in the Egan Range south of Ely, Nevada, in Short papers in the geologic and hydrologic sciences: U. S. Geol. Survey Prof. Paper 424-B, p. B178-B181.

Thompson, G. A., and Sandberg, C. H., 1958, Structural significance of gravity surveys in the Virginia City-Mount Rose area,Nevada and California:Geol. Soc. American Bull. 69, p. 1269-1282.

Vacquier, V., Steenland, N. C., Henderson, R. G., and Zietz, I., 1951, Interpretation of aeromagnetic maps Geol. Soc. America Mem. 47, 151 p.

Woollard, G. P., 1958, Results for a gravity control network at airports in the United States: Geophysics, v. 23 , no. 3 , p. $520-536$. 